\title{
SPRAWOZDANIE Z DZIAŁALNOŚCI TOWARZYSTWA PRZYJACIÓŁ ARCHIWUM DIECEZJALNEGO IM. BL. WINCENTEGO KADLUBKA W KIELCACH ZA ROK 2016
}

Działalność Towarzystwa Przyjaciół Archiwum Diecezjalnego im. bł. Wincentego Kadłubka w Kielcach w latach 2012-2014 została opisana w pierwszym sprawozdaniu ${ }^{1}$. Za rok 2015 ukazały się dwa sprawozdania odpowiednio - w czasopiśmie ogólnopolskim oraz w lokalnym ${ }^{2}$. Niniejsze sprawozdanie stanowi kontynuację i obejmuje rok 2016. Z działalnością Towarzystwa związane było Koło Historyczne Wyższego Seminarium Duchownego w Kielcach. ${ }^{3}$

Towarzystwo organizowało działania naukowe w ramach programu Rola Kościoła jako wychowawcy i stróża kultury narodowej. Celem programu było skupianie inicjatyw i badań służących tworzeniu środowiska naukowego do badań nad kościelnymi dobrami kultury4. Spotkania odbywały się w cyklu comiesięcznym. Relacje ze spotkań były zamieszczane na stronie internetowej oraz na Facebook ${ }^{5}$. W ramach czterech posiedzeń odbytych w pierwszej połowie 2016 roku, trzy miały charakter naukowy, jedno związane było z obchodami roczni-

${ }^{1}$ P. Kardyś, Sprawozdanie z działalności Towarzystwa Przyjaciół Archiwum Diecezjalnego im. bt. Wincentego Kadlubka w Kielcach, „Archiwa, Biblioteki i Muzea Kościelne” (dalej: ABMK), 103 (2015) s. 421-426.

${ }^{2}$ W. Cedro, Sprawozdanie z działalności Towarzystwa Przyjaciót Archiwum Diecezjalnego im. bt. Wincentego Kadtubka w Kielcach za rok 2015, ABMK, 105 (2016) s. 435-441. A. Kania, Sprawozdanie z działalności Towarzystwa Przyjaciót Archiwum Diecezjalnego im. bt. Wincentego Kadtubka w Kielcach za rok 2015, „Świętokrzyskie Studia Archiwalno-Historyczne” (dalej: ŚSAH), 5 (2016) s. 399-407.

${ }^{3}$ P. Misztal, Sprawozdanie z działalności Koła Historycznego Wyższego Seminarium Duchownego w Kielcach, „Kieleckie Studia Teologiczne” (dalej: KST), 15 (2016) s 387-397.

${ }^{4}$ A. Kwaśniewski, Program naukowy Rola Kościoła jako wychowawcy i stróża kultury narodowej, ss. 1 - źródło http://www.archiwum.diecezja.kielce.pl/index.php/program-naukowy (dostęp 26.08.2017)

$5 \mathrm{http} / /$ www.archiwum.diecezja.kielce.pl/index.php/towarzystwo-przyjacio-archiwum-diecezjalnego-w-kielcach/posiedzenia (dostęp: 26.08.2017) https://www.facebook.com/towarzystwoprzyjaciolarchiwumdiecezjalnego/ (dostęp: 26.08.2017) 
cy śmierci patrona Towarzystwa. Z przeszłością kościelną terenów wchodzących w skład diecezji kieleckiej związany był referat prof. dr hab. Jerzego Szczepańskiego zatytułowany Mapy, plany i rysunki architektoniczne skasowanych klasztorów w guberni radomskiej (12.01.2016). W pierwszą rocznicę śmierci wybitnego badacza polskiej kultury religijnej, ks. prof. Daniela Olszewskiego, zorganizowano wspomnienia pośmiertne przedstawione przez prof. dr hab. Adama Massalskiego oraz ks. dr Pawła Tambora (09.02.2016). Śp. ks. D. Olszewski był członkiem współzałożycielem Towarzystwa Przyjaciół, ponadto funkcjonuje w świadomości naukowego środowiska kieleckiego jako wybitny historyk Kościoła. W tym kontekście zrozumiała jest rekordowa frekwencja na spotkaniu wspomnieniowym - przybyło ponad 100 osób. Kilka relacji z tego wydarzenia zostało opublikowanych $\mathrm{w}$ gazetach oraz czasopiśmie naukowym ${ }^{6}$.

Członkowie Towarzystwa zorganizowali obchody Międzynarodowego Dnia Archiwów (09.06.2016). Był to dzień otwarty w Archiwum Diecezjalnym w Kielcach. W programie zrealizowano zwiedzanie magazynów. Ponadto z okazji 1050. rocznicy Chrztu Polski zorganizowano w czytelni naukowej wystawę najstarszych ksiąg metrykalnych. Kornelia Major jako członek Towarzystwa oraz prezes Świętokrzyskiego Towarzystwa Genealogicznego „Świętogen” prezentowała księgi oraz prowadziła rozmowy z przybywającymi na temat prezentowanych archiwaliów. W ramach programu Rola Kościoła dr Agnieszka Fluda-Krokos (Uniwersytet Pedagogiczny w Krakowie) przedstawiła referat Inwentarz klasztoru poaugustiańskiego $w$ Książu Wielkim w roku 1900 spisany ${ }^{7}$. Przedstawione działania naukowe organizowane były w ramach comiesięcznych spotkań. Nieco inny charakter kulturotwórczy miało spotkanie związane ze wspomnieniem śmierci bł. Wincentego Kadłubka i złączonym z nim ceremoniałem Katolickiego Dnia Kobiet (08.03.2016).

$\mathrm{Z}$ działaniami realizowanymi w poprzednich latach związane były dwie publikacje - sprawozdanie dotyczące konferencji naukowej o bożogrobcach oraz artykuł związany z referatem wygłoszonym na konferencji na temat elenchusów oraz artykuł nawiązujący do referatu o kancelarii dziekana kurzelowskiego wygłoszonego na forum Towarzystwa ${ }^{8}$. W opublikowanej bibliografii piśmiennictwa dotyczącego bibliotek kościelnych, odnotowane zostały informacje na temat ba-

${ }^{6}$ M. Bieroński, Kalendarium Wyższego Seminarium Duchownego w Kielcach, „Obecni”, 15 (2015) nr 32, s. 80. K. Dobrowolska, Pamięci ks. prof. Olszewskiego, „Niedziela”, 59 (2016) nr 5, (wkładka kielecka), s. VI; S. Konarska, Ad perpetuam rei memoriam. Whołdzie śp. ks. prof. dr. hab. Danielowi Olszewskiemu, KST, 15 (2016) s. 379-381. S. Osowski, Wspomnienie o śp. ks. prof. Danielu Olszewskim w pierwsza rocznicę śmierci, „Gazeta jędrzejowska”, 24 (2016) nr 7, s. 6.

${ }^{7}$ [Plakat informujący o programie dnia otwartego] http://www.archiwum.diecezja.kielce.pl/index.php/fb/62-plakaty/484-2016-06-04-06-19-01 (dostęp: 26.08.2017).

${ }^{8}$ M. Kowalski, Sprawozdanie z ogólnopolskiej konferencji: „Bożogrobcy w stużbie Sanktuarium Świętego Grobu Jerozolimskiego Naszego Pana Jezusa Chrystusa w Miechowie”. Miechów 27-28 maja 2015, KST, 15 (2016) s. 383-385. P. Kardyś, Rubrycele i schematyzmy diecezji żmudzkiej z lat 1853-1914 zachowane w Archiwum Diecezjalnym w Kielcach, „Nasza Przeszłość”, 126 (2016) s. 291-319. R. Prejs, Kancelaria dziekańska w Kurzelowie w XIX wieku. Przyczynek do dziejów kancelarii dziekańskich w Królestwie Polskim, ŚSAH, 5 (2016), s.71-80. 
dań dotyczących bibliotek diecezji kieleckiej. Badania te były związane z pracą Towarzystwa9 ${ }^{9}$ W ramach refleksji prowadzonej nad osiągnięciami i planami rozwoju Towarzystwa ukazało się opracowanie omawiające całokształt dotychczasowych prac. W artykule wskazano również na miejsce Towarzystwa w tradycji archiwistycznej diecezji kieleckiej ${ }^{10}$. Odrębną pracę opublikowano w związku z kwestią wykorzystania kościelnych dóbr kultury jako narzędzia w pogłębieniu wiary. Rozważania na temat kwestii formacyjnej związane były ze skupioną wokół archiwum społecznością wiernych świeckich - członków i sympatyków Towarzystwa ${ }^{11}$.

Badania naukowe prowadzone w ramach Towarzystwa były prezentowane na kilku konferencjach. W dniach 4-5 października 2016 roku odbyła się w Chmielniku konferencja zatytułowana Kto ratuje jedno życie - ratuje cały świat. Na konferencji przedstawiony został referat - Polacy ratujacy Żydów na terenie diecezji kieleckiej w latach 1939-1945 (ks. dr A. Kwaśniewski) ${ }^{12}$. Referat zaowocował publikacją o nieznanych przykładach chrześcijańskiego heroizmu ${ }^{13}$.

Dwie kolejne konferencje były związane z badaniami nad dziejami historycznych księgozbiorów. W dniach 29. 09. - 1.102016 roku odbyła się we Wrocławiu konferencja międzynarodowa - „Książka Dawna i jej właściciele”, na której został przedstawiony referat Księgozbiór Kapituly Kieleckiej $w$ świetle inwentarza z 1650 roku (autor ks. dr A. Kwaśniewski) ${ }^{14}$. W dniach 17-18 listopada 2016 roku odbyła się II ogólnopolska konferencja oprawoznawcza - „Introligatorzy $i$ ich klienci", na której został przedstawiony referat Superekslibrisy w Bibliotece Kapituły Kieleckiej (autor ks. dr A. Kwaśniewski). ${ }^{15}$

Działające od 2013 roku Studium Historii Diecezji Kieleckiej w roku akademickim 2015/2016 zakończyło trzyletni cykl wykładów w Kielcach oraz dwuletni cykl wykładów w Miechowie. Po zakończeniu wykładów absolwenci i wolni słuchacze studium, rozpoczęli działalność samokształceniową na forum Towarzystwa. Powstały trzy grupy samokształceniowe - w Kielcach, Nowym Korczynie

${ }^{9}$ R. Żmuda, Bibliografia piśmiennictwa o polskich bibliotekach kościelnych za lata 2011-2015, „Fides. Biuletyn Bibliotek Kościelnych”, 22 (2016) nr 2, s. 190, 211, 216, 230.

${ }^{10}$ A. Kwaśniewski, Towarzystwo Przyjaciót Archiwum Diecezjalnego imienia błogosławionego Wincentego Kadlubka w Kielcach w latach 2012-2015, w: Nova et vetera. Aktualne problemy archiwów diecezjalnych w Polsce, red. W. Żurek, Lublin 2016, s. 133-172.

${ }^{11}$ A. Kwaśniewski, Kościelne Dobra Kultury jako narzędzie formacji Christi fideleslaici przy Archiwum Diecezjalnym w Kielcach, „Veritati et Caritati”, 7 (2016) s. 115-143.

${ }^{12}$ A. D[ziarmaga], Kto ratuje jedno życie ratuje caly świat, „Niedziela”, 59 (2016) $\mathrm{nr} 40$, (wkładka kielecka), s. III; Konferencja naukowa w Chmielniku, „Niedziela”, 59 (2016) nr 40, (wkładka kielecka), s. III; A. D[ziarmaga], Heroizm ponad wszystko, „Niedziela”, 59 (2016) nr 43, (wkładka kielecka), s. I, VI.

${ }^{13}$ A. Kwaśniewski, Polacy ratujący Żydów na terenie diecezji kieleckiej w latach 1939-1945. Nieznane przypadki heroizmu chrześcijańskiego, w: Pomoc świadczona ludności żydowskiej przez Polaków w latach 1939-1945 ze szczególnym uwzględnieniem Kielecczyzny, red. J. Gapys, A. Dziarmaga, Kielce 2016, s. 135-155.

${ }_{14} \mathrm{https}: / /$ ossolineum.pl/index.php/konferencja-ksiazka-dawna-i-jej-wlasciciele-stan-badan-opracowanie-perspektywy/ (dostęp: 26.08.2017).

${ }^{15} \mathrm{https}$ ://www.facebook.com/events/1719084018334665/ (dostęp: 26.08.2017). 
i Miechowie ${ }^{16}$. W czasie spotkań w grupach przygotowywane były programy objazdów naukowych służących poznawaniu dziedzictwa kultury chrześcijańskiej. Praca polega na zapoznawaniu się z literaturą przedmiotu oraz przygotowywaniu stosownych referatów. Pierwszy objazd naukowy po obiektach sakralnych i historycznych gminy Charsznica (kościoły w Charsznicy, Uniejowie i Chodowie) odbył się w dniu 27 sierpnia $2016^{17}$. Trzydniowy wyjazd na Grodzisko k. Skały odbył się w dniach 18-20 listopada 2016 r. ${ }^{18}$ Działalność samokształceniowa i objazdy naukowe były zapowiadane i relacjonowane na Facebook ${ }^{19}$. Wykształcona w Studium grupa inteligencji katolickiej przyczyniła się do wytworzenia w Towarzystwie nurtu popularyzacji historii Kościoła. Działalność ta egzystuje obok nurtu badawczego skupionego w ramach programu Rola Kościoła jako wychowawcy i stróża kultury narodowej.

W pewnym sensie przedłużeniem nurtu popularyzacyjnego jest udział członków i sympatyków Towarzystwa w kulcie religijnym sprawowanym w sanktuariach diecezji kieleckiej. W roku 2015 odbyła się pierwsza pielgrzymka diecezjalna do relikwii św. Kingi w Nowym Korczynie. Następnie, po zakończeniu pielgrzymki zainicjowano comiesięczne czuwania w miejscowym sanktuarium św. Kingi ${ }^{20}$. Podobną formę złożoną z czuwań i pielgrzymki ma organizowany kult religijny w Sanktuarium Grobu Bożego w Miechowie ${ }^{21}$. W roku 2015 zostały zainicjowane czuwania w Sanktuarium Matki Bożej Łaskawej w Szczaworyżu ${ }^{22}$. W czasie czuwań i pielgrzymek rola osób związanych z Towarzystwem polegała na modlitwie, spełnianiu funkcji liturgicznych oraz na opiece i edukacji religijnej świadczonej wobec pielgrzymów. Działalność związana z kultem religijnym posiadała zapowiedzi i relacje prezentowane na Facebook ${ }^{23}$.

${ }^{16}$ Towarzystwo Przyjaciół Archiwum Diecezjalnego im. bł. Wincentego Kadłubka w Kielcach, dokumentacja kancelaryjna.

${ }^{17}$ A. Dziarmaga, Studium Historii Diecezji Kieleckiej, „Niedziela”, 59 (2016) nr 38, (wkładka kielecka), s. I, VI. M. Nowak, M. Spława-Neyman, Studium wyjazdowe w gminie Charsznica, „Gazeta Miechowska", 9 (2016), nr 263, s. 14.

${ }^{18}$ A. D[ziarmaga], Odkrywaja miejsca i ludzi. Odwiedzili błogosławionych, „Niedziela”, 60 (2017) nr 3, (wkładka kielecka), s. VI; M. Misztal, M. Spława-Neyman, Relacja z objazdu naukowego SHDK. 18-20.11.2016, „Kronika Miasta i Gminy Skała”, nr 48 (98), styczeń-luty 2017, s. 13. M. Spława-Neyman, Od bt. Maksymiliana Binkiewicza do bt. Salomei. Relacja z objazdu naukowego SHDK, „Echo Żarnowca. Gazeta samorządowa”, listopad-grudzień 2016, nr 166, s. 15.

${ }^{19} \mathrm{https}$ ://www.facebook.com/groups/1655306088077804/ (dostęp: 26.08.2017).

${ }^{20}$ W. Burzawa, Oddali cześć św. Kindze, „Niedziela”, 59 (2016) nr 6, (wkładka kielecka), s. VIII.

${ }^{21}$ A. D[ziarmaga], Czuwali w Miechowie, „Niedziela”, 59 (2016) nr 2, (wkładka kielecka) s. II; A. Dziarmaga, 3 Diecezjalna Pielgrzymka do Pustego Grobu, „Niedziela”, 59 (2016) nr 18, (wkładka kielecka), s. II.

${ }^{22}$ A. Dziarmaga, Szczaworyskie czuwanie, „Niedziela” 59 (2016) nr 43, (wkładka kielecka), s. VIII. Czuwania u Matki Bożej Łaskawej, „Tygodnik Ponidzia”, 23 (2016) nr 25, s. 2; K. Dobrowolska, Szczaworyż. Na czuwania u Matki Bożej Łaskawej, „Niedziela”, 59 (2016) nr 18, (wkładka kielecka), s. III; Wierni w Szczaworyżu, „Tygodnik Ponidzia”, 23 (2016) nr 35, s. 6; Z wizyta u św. Jakuba w Szczaworyżu, „Tygodnik Ponidzia”, 23 (2016) nr 29, s. 6.

${ }^{23} \mathrm{https} / / /$ www.facebook.com/towarzystwoprzyjaciolarchiwumdiecezjalnego/ (dostęp: 26.08.2017). 
W ramach współpracy z Świętokrzyskim Uniwersytetem Trzeciego Wieku popularyzowana była wiedza na temat dziejów Kościoła. Wykłady były wygłoszone przez ks. dr Andrzeja Kwaśniewskiego w ramach sekcji uniwersytetu o nazwie Klub nad Silnica. Tematyka wykładów: Sanktuarium Grobu Bożego w Miechowie (27.02.2016), Sanktuarium św. Kingi w Nowym Korczynie (07.05.2016), Chrzest Mieszka I (15.10.2016), Obchody tysiaclecia chrztu Polski w Kielcach $i$ Wiślicy $(10.12 .2016)^{24}$. Wymienione wykłady zrealizowano w ramach kształcenia w roku akademickim 2015/2016 oraz 2016/2017. Podjęta współpraca dała możliwość realizacji celów statutowych Towarzystwa - ,upowszechnianie wiedzy o historii Kościoła" (statut, paragraf 6, p.5).

W roku 2016 ukazały się opracowania na temat członków Towarzystwa. Obszerny artykuł na temat prac ks. D. Olszewskiego wykonanych dla diecezji kieleckiej, opublikował ks. dr A. Kwaśniewski ${ }^{25}$. W pracy poświęconej wykładowcom historii Kościoła zamieszczone zostały życiorysy ks. D. Olszewskiego oraz ks. A. Kwaśniewskiego ${ }^{26}$. Ponadto opublikowane zostały sprawozdania na temat konferencji poświęconej pamięci ks. D. Olszewskiego. Konferencja zorganizowana została przez Akademię „Ignatianum” w Krakowie. W ramach konferencji przedstawiony został m.in. referat na temat dorobku naukowego ks. D. Olszewskiego $^{27}$. Na uwagę zasługuje również wspomnienie o ks. D. Olszewskim oraz biogram zamieszczony w Nowej encyklopedii chrześcijaństwa ${ }^{28}$. W czasopiśmie diecezjalnym ukazało się krótkie wspomnienie o śp. ks. Stanisławie Adamczyku, który był związany z Towarzystwem poprzez uczestnictwo w wykładach Studium $^{29}$.

${ }^{24} \mathrm{http}: / /$ sutw-kielce.pl/old/kultura-rozrywka-rekreacja/klub-nad-silnica/1381-sanktuarium-w-miechowie-grob-bozy.html

http://sutw-kielce.pl/old/rozklad-zajec/program-klubu-nad-silnica/103-oferta-programowa.html http://mhki.kielce.eu/calendar/2016/12/10

http://www.sutw-kielce.pl/index.php?id=565 (dostęp: 26.08 .2017 )

${ }^{25}$ A. Kwaśniewski, Wspomnienie pośmiertne o księdzu profesorze Danielu Olszewskim (19342015). Prace wykonane dla diecezji kieleckiej, „Kielecki Przegląd Diecezjalny” (dalej: KPD), 92 (2016) z. 1, s. 154-169. [Przedruk:] A. Kwaśniewski, Ksiadz profesor Daniel Olszewski (19342015). Prace wykonane dla diecezji kieleckiej, w: Nasze Gene-historie, Kielce 2017, s. 65-74.

${ }^{26}$ J. Walkusz, Sekcja historii Kościoła 1964-2014, Pelplin 2016, s. 67, 70, 83, 193-194, $122-$ 224.

${ }^{27}$ K. Jarkiewicz, Ogólnopolska konferencja naukowa „, Polska kultura religijna”, „Ignatianum. Półrocznik Akademii Ignatianum w Krakowie”, 16 (2016) nr 1, s. 4-5; A. Starczewska-Wojnar, Konferencja naukowa „, Polska kultura religijna”, Kraków 8-10 grudnia 2015 r., ŚSAH, 5 (2016) s. 449453, [referat: Dorobek naukowy ks. prof. dr. hab. Daniela Olszewskiego, autor ks. A. Kwaśniewski.]

${ }^{28}$ W. Iwańczak, Ksiadz Profesor Daniel Olszewski, „Rocznik Oddziału Polskiego Towarzystwa Historycznego w Skarżysku-Kamiennej. Z dziejów regionu i miasta”, 7 (2016) s. 161-163; A. Kwaśniewski, Olszewski Daniel, w: Nowa encyklopedia chrześcijaństwa, red. H. Witczyk, Kielce 2016 , s. 556.

${ }^{29}$ R. Borecki, A. Sadrak, Wspomnienie pośmiertne o ks. kan. Stanistawie Adamczyku (19462015), KPD, 92 (2016) z. 2, s. 358-362. 